\title{
The Effect of Working Capital, Liquidity and Leverage on Profitability
}

\section{Rista Bintara}

Accounting Study Program, Faculty of Economics and Business, Mercu Buana University Jl. Raya Meruya Selatan Kembangan 11650 West Jakarta Indonesia

DOI: $10.36348 /$ sjef.2020.v04i01.005

| Received: 15.01.2020 | Accepted: 22.01.2020 | Published: 24.01.2020

*Corresponding author: Rista Bintara

\section{Abstract}

This research was conducted with the aim of: 1) To analyze the effect of working capital turnover on profitability; 2) To analyze the effect of liquidity on profitability; 3) To analyze the effect of leverage on profitability. This type of research used in this study is casual associative research (causal associative research). The population of this research are property, real estate, and building construction companies which are included in the Kompas 100 index which are listed on the Indonesia Stock Exchange (IDX) in the period 2013-2018. The sampling technique is using purposive sampling technique. The analytical method used to test hypotheses is multiple regression analysis. The results of the study show that: 1) Working capital turnover has no effect on profitability; 2) Liquidity has no effect on profitability; and 3) Leverage has a negative effect on profitability.

Keywords: Working Capital Turnover, Liquidity, Leverage, Profitability.

Copyright @ 2020: This is an open-access article distributed under the terms of the Creative Commons Attribution license which permits unrestricted use, distribution, and reproduction in any medium for non-commercial use (NonCommercial, or CC-BY-NC) provided the original author and source are credited.

\section{INTRODUCTION}

In today's modern era, every company must be able to compete continuously. Increasing competition in both the domestic and international markets requires companies to be able to maintain or gain competitive advantage by giving full attention to the company's operational and financial activities.

The performance of a company's finances is often evaluated using simple ratios obtained from the company's financial statements themselves. Kasmir [1] states that profitability ratios are a value that shows the ability of companies in managing and managing assets, because in calculating profitability ratios basically come from financial statements in which there will be found the results of an analysis of a number of ratios which subsequently the ratio will provide value to certain aspects of the company's financial statements.

According to Sartono [2] profitability can measure how much growth a company earns in terms of sales, assets and profits for its own capital. Management is required to increase revenues or operating profits, to finance all company activities, increase assets and pay off company obligations. The measure of success of a manager can be seen from the ability to create profitability. Increasing profitability is the most important task for a manager. Managers are constantly looking for ways to change the company in order to increase profitability.

According to Nugroho [3] a company can maximize its profits if the financial manager knows the factors that have a major influence on profitability, the company can determine steps to overcome problems and minimize the negative impacts that arise. All factors contained in a company have an influence on the company's ability to make a profit. To maximize each of these factors, asset management, cost management and debt management are needed. In addition, according to Nugroho, there are many factors that affect a company's profitability. These factors can be measured using financial ratios, financial ratios such as current ratios, working capital turnover, sales growth, company size and debt ratios, can be used to determine the effect of each variable on company profitability. In this study, research will be conducted on working capital turnover, liquidity (current ratio) and leverage (debt ratio) which affect profitability.

High company growth is preferred to take advantage of investments that have good prospects. The greater the expected sales, the greater the profitability of the company. The increase in sales followed by an increase in operating results will further increase the confidence of outsiders towards the company. With the increasing confidence of outsiders (creditors), the 
proportion of debt is greater than equity. This is based on the creditor's confidence in the funds invested in the company guaranteed by the amount of assets owned by the company. As a tool to measure the profitability of a company used return on assets (ROA). This ratio is the most important ratio among the existing profitability ratios. ROA ratio is often used by top management to evaluate business units in multidivisional companies [4].

Working capital is the amount of funds used to fund the company's operational activities and to generate profitability. Investments made by the company are expected to provide benefits in a short time. Working capital management is related to the company's ability to generate profits [5]. Yulianita \& Isynuwardhana [4] found that working capital turnover affects profitability. While research by Wijaya \& Isnaini [6] found that working capital turnover did not affect profitability.

Another factor that can have an impact on profitability is liquidity. Liquidity ratios provide an overview of a company's ability to settle short-term debt. The high liquidity ratio means better company performance, because creditors will be interested in providing short-term loans to the company, which makes the company's activities run as they should and will have an impact on the company's profitability [6]. Wijaya \& Isnaini [6] found that liquidity affects profitability. While research by Yulianita \& Isynuwardhana [4] found that liquidity had no effect on profitability.

The next factor that is likely to have an impact on profitability is leverage. Good debt management to finance operational activities can increase company profitability. Putra and Badjra [10] suggested that the use of debt to fund the company's operational activities can provide benefits to the company, but if the company does not pay attention to the proportion of leverage it can cause a decrease in profitability because the accumulated debt will cause a fixed interest expense. Putranto [10] found that leverage affects profitability. Whereas research by Wijaya \& Isnaini [6] found that leverage has no effect on profitability.

The researcher chose the property, real estate and building construction company because property, real estate and building construction companies play an important role in the field of economy and development in Indonesia. This sector is also one indicator to assess a country's economic development.

Based on the description above, the authors are interested in conducting a study entitled "The Effect of Working Capital Turnover, Liquidity, and Leverage on Profitability in Property, Real Estate, and Building Construction Companies that went public in the Kompas 100 Index in 2013-2018".

\section{LITERATURE REVIEW Agency Theory}

Jensen and Meckling [8, 7] explain the agency relationship in agency theory that companies are a collection of contracts (nexusof contracts) between economic resource owners (principals) and managers (agents) who take care of the use and control of resources the. Agency theory (agency theory) arises after the phenomenon of separate ownership of companies with management found in large modern companies so that classical corporate theory can no longer be used as a basis for such company analysis.

\section{Working Capital Turnover}

Working capital is needed in carrying out the activities of a company, and working capital is very important in supporting the smooth operation of the company's operations, so the company can run well on an ongoing basis [9]. Working capital is a company's investment in short-term assets such as cash, securities (securities), trade receivables and inventories. Net working capital is current assets minus current debt, for example bank loans, promissory notes, trade debts, wages and tax debts.

According Riyanto [2] Working capital is always in a state of operation or spinning within the company as long as the company concerned is in a business state. The working capital turnover period starts from the time when cash is invested in the components of working capital to where it returns to cash. The shorter the period means the faster or higher the turnover rate. The length of the revolving period of each component of working capital depends on how long the rotation period of each component of the working capital is. The level of working capital or current assets can also be calculated from the balance sheet and income statement at any given time. The formula is as follows:

$$
\text { Working Capital Turnover }=\frac{\text { Sales }}{\text { Current Assets }- \text { Current Liabilities }}
$$

\section{Liquidity}

According to Fahmi [10] Liquidity ratio is the ability of a company to meet its short-term obligations in a timely manner. Examples of paying for electricity, PDAM water, employee salaries, technician salaries, overtime salaries, telephone bills and so on. Therefore, the liquidity ratio is often referred to as short term liquidity. Current debt is a payment obligation in one year or a normal operating cycle in business. The availability of cash sources to meet these obligations comes from cash or cash conversion from current assets. To measure liquidity the researcher uses the current ratio. Current ratio is the ratio between the amount of current assets and current debt $[11,12]$. High $\mathrm{CR}$ provides a good indication of collateral for shortterm creditors in the sense that at any time the company has the ability to pay off short-term financial obligations. However, a high CR also indicates that 
some working capital is not rotating or experiencing unemployment and will negatively affect the ability to obtain profit/profitability [12]. The reduced ability of a company to make a profit will also cause a decrease in the returns that will be obtained by investors. Here is the formula used to calculate the current ratio:

$$
\text { Current Ratio }=\frac{\text { Current Assets }}{\text { Current Liabilities }}
$$

\section{Leverage}

According to Fahmi [10], leverage ratio is a measure of how much a company is financed with debt. The use of debt that is too high will endanger the company because the company will enter into extreme leverage (extreme debt) that is the company is trapped in a high level of debt and it is difficult to release the debt burden. Therefore, the company must balance how much debt is worth taking and from which sources can be used to pay off debt. To measure the leverage of researchers using Debt to Equity Ratio (DER). DER is a ratio that illustrates the ratio of debt and equity in corporate funding and shows the ability of the company's own capital to meet all its obligations Sawir, 2000 in Bintara [12]. The formula is as follows:

$$
\text { Debt to Equity Ratio }=\frac{\text { Total Liabilities }}{\text { Total Shareholder's equity }}
$$

\section{Profitability}

Profitability is the main objective of the establishment of the company. Profitability plays an important role for the company's future. Companies need to have good profitability for business continuity [13]. Profitability is one indicator to assess the level of effectiveness of management performance in running a company by looking at the level of benefits obtained [14]. To measure profitability, researchers use return on assets (ROA). ROA is one ratio that measures the level of profitability of a company. ROA is used to determine the amount of net profit that can be obtained from the company's operations using all of his wealth. High and low ROA depends on the management of company assets by management that illustrates the efficiency of the company's operations. The higher the ROA the more efficient the company's operations and vice versa, the lower ROA can be caused by the number of company assets that are unemployed, investments in excess inventory, excess paper money, fixed assets operating below normal and others occur on the stock exchange [12]. The formula is as follows:

$$
R O A=\frac{\text { Earning After Tax }}{\text { Total Assets }}
$$

\section{Previous research}

Previous research that can support this research is as follows: Putranto [15] in his research entitled "The Effect of Diversification, Leverage, and Inflation Strategies on the Profitability of Food \& Beverage Companies". The results showed that the diversification strategy had a positive effect on company profitability, leverage had a positive effect on company profitability but was not in accordance with the hypothesis, while inflation did not affect the company's profitability.

Wijaya and Isnani [16] in their study entitled "The Effect of Working Capital Efficiency, Liquidity, and Solvency on the Profitability of Pharmaceutical Companies". The results showed that the Working Capital Turnover (WCT), Debt to Equity Ratio (DER) partially had a negative and not significant effect on Return on Assets (ROA). Current Ratio (CR) has a positive and significant effect on Return On Assets (ROA).

Yulianita and Isynuwardhana [17] in their study entitled "The Effect of Working Capital Turnover, Liquidity, and Leverage on Profitability (Empirical Study of Consumer Goods Companies Listed on the Indonesia Stock Exchange for the 20152017 Period)". The results showed that simultaneously showed Working Capital Turnover (WCOT), Liquidity (CR), and Leverage (DER) significantly influence Profitability (ROA). Partially, Working Capital Turnover (WCOT) has a significant effect on profitability (ROA), while Liquidity (CR) and Leverage (DER) have no significant effect on profitability (ROA).

Putra \& Pangestuti [18] in his research entitled "Effect of Market Structure, Competition, Diversification, and Credit Risk on Bank Profitability with Bank Size as a Control Variable (Study of Banks Listed on the Indonesia Stock Exchange)". The results of this study indicate that market structure, competition and diversification have a significant positive effect on profitability, but credit risk has a significant negative effect on profitability.

\section{Framework}

Based on the theoretical basis and the results of previous studies and the problems that have been raised, then as a basis for formulating a hypothesis, the following framework is presented in the research model in the following figure: 


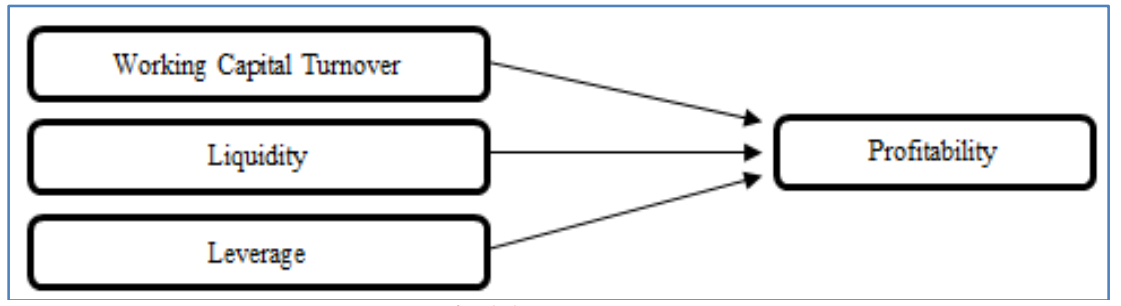

Fig-1.1: Framework

\section{HYPOTHESIS}

The research hypotheses proposed are as follows: Ha1 = Working Capital Turnover affects Profitability. $\mathrm{Ha} 2$ = Liquidity affects Profitability. Ha3 = Leverage affects profitability.

\section{RESEARCH METHODS}

\section{Types of research}

This research is causal research. The type of research used in this study is casual associative research (causal associative research). According to Sanusi [11], associative-causal research is research that looks for relationships between two or more variables. The purpose of associative research is to look for relationships between one variable and another.

\section{Definition of Variable Operations}

The variables used in this study consisted of the dependent variable and the independent variable. Operational research variables on the Effects of Working Capital Turnover, Liquidity, and Leverage on Profitability can be summarized in table 1.1.

Table-1.1: Operationalization of Variables

\begin{tabular}{|l|l|c|c|}
\hline \multicolumn{1}{|c|}{ Type of Variable } & \multicolumn{1}{|c|}{ Operational Definition } & Formula & Scale \\
\hline Dependent & \multicolumn{1}{|c|}{$\begin{array}{l}\text { ROA } \\
\text { Profitability } \\
\text { of management performance in running a } \\
\begin{array}{l}\text { company by looking at the level of benefits } \\
\text { obtained }\end{array}\end{array}$} & Ratio \\
\hline Independent & $\begin{array}{l}\text { Working capital is always operating or rotating } \\
\text { Within the company as long as the company } \\
\text { concerned is in business }\end{array}$ & Sales & Ratio \\
\hline Liquidity & $\begin{array}{l}\text { The ratio used to measure the companyt absets - Current Liabilities } \\
\text { to meet short-term obligations that must be met }\end{array}$ & Current Ratio & Ratio \\
\hline Leverage & $\begin{array}{l}\text { The ratio used to measure how much the } \\
\text { company is financed with debt }\end{array}$ & Debt to Equity Ratio & Ratio \\
\hline
\end{tabular}

\section{Data Types and Sources}

The data used in conducting this research is secondary data, that is data obtained through intermediaries from both parties and certain media that support this research. The data used in this study are secondary data in the form of financial statements of property companies, real estate, and building construction which are included in the Kompas 100 index listed on the Indonesia Stock Exchange during 2013-2018 obtained from the Indonesia Stock Exchange website (www.idx.co.id) and the official website of each of these companies.

\section{Population and Research Samples}

The population in this study are property, real estate, and building construction companies which are included in the Kompas 100 index which are listed on the Indonesia Stock Exchange (IDX) during 2013-2018. The sample is part of the population used to estimate population characteristics. The sampling technique is using purposive sampling technique. According to Widyani [11] the purposive sampling method is the selection of samples on the basis of the suitability of the characteristics of the sample with the specified sample selection criteria. The sample criteria used in this study are:

- Property, real estate, and building construction companies which are included in the Kompas 100 index which are listed on the Indonesia Stock Exchange (IDX) during 2013-2018.

- Publish audited financial statements for the period 2013-2018

- The company did not experience a loss during the study year.

- Data owned by the company are complete and in accordance with the variables studied.

According to the criteria above, the number of samples used were 13 companies during the 6 periods namely 2013, 2014, 2015, 2016, and 2018. Then the number of samples obtained was 13 companies x 6 periods $=78$ data to be used in this study. 


\section{DATA COLLECTION TECHNIQUE}

Data collection methods in this study are library study methods and documentation methods. Literature study method by studying literature and reviewing a variety of literature literature such as various journals, articles and other literature books that support the research process. While the documentation method is the process of collecting data by recording documents related to this study.

\section{ANALYSIS METHOD Descriptive statistics}

Descriptive statistics in this study are used to provide a description of the character of the research variable using a frequency distribution table that shows the mode number, the range of scores and the standard of division

\section{Classic assumption test}

This research was conducted with a simple regression analysis. The use of simple regression analysis must be free from testing classic assumptions. For this reason, before a simple regression analysis is carried out, classical assumptions must be tested first. Testing classic assumptions is done using the normality test, multicollinearity test, heterokedasticity test and autocorrelation test.

\section{Hypothesis testing}

In this study the authors used three independent variables and three dependent variables. The analytical method used to test the hypothesis is the multiple regression method, namely regression used to find out how much influence the independent variable has on the dependent variable, with a simple linear regression analysis that aims to meet the researchers' expectations regarding the Effect of Working Capital Turnover, Liquidity, and Leverage Against Profitability. Regression analysis using SPSS software version 25. The regression equation is as follows: $Y=\alpha+\beta_{1} X_{1}$ $+\beta_{2} X_{2}+\beta_{3} X_{3}+\varepsilon_{1}$



In this study, the significance level $(\alpha)$ of 0.05 or $5 \%$ was used. To test whether the proposed hypothesis is accepted or rejected, a test of research variables is carried out by simultaneously testing through the simultaneous significance test (F statistic test), which intends to explain the effect of the independent variable on the dependent variable. Meanwhile, to test each variable partially, it is carried out by means of an individual parameter significance test (statistical $t$ test) which aims to find out whether the independent variable influences the dependent variable, and which of the dominant variables influence the dependent variable.

\section{RESEARCH RESULTS AND DISCUSSION Research Data Description}

The following are descriptive statistical results about the research variables as follows:

Table-1.2: Descriptive Statistics Results

\begin{tabular}{|c|c|c|c|c|c|}
\hline Variabel & $\mathbf{N}$ & Minimum & Maximum & Mean & Std. Deviation \\
\hline X1 & 78 & $-0,22$ & 0,40 & 0,05 & 0,086 \\
\hline X2 & 78 & 0,65 & 7,76 & 2,06 & 1,380 \\
\hline X3 & 78 & 0,28 & 5,37 & 1,63 & 1,212 \\
\hline Y & 78 & 0,00 & 0,22 & 0,06 & 0,038 \\
\hline \multicolumn{7}{|c|}{ Source: Data processed (2019) }
\end{tabular}

The following are descriptive statistical results about the research variables as follows: Working Capital Turnover Variables have an average value of 0.05 times with a standard deviation of 0.086 times, which means large data variations (more than 0.038 times the mean). Working Capital Turnover Variables range from the lowest value of -0.22 times, namely the company Alam Sutera Realty Tbk in 2016. up to the highest value of 0.40 times the company Alam Sutera Realty Tbk in 2014. Liquidity variables have an average value of $2,06 \%$ with a standard deviation of $1.380 \%$, which means that the data variation is small (less than $0.678 \%$ of the mean). Liquidity variable ranges from the lowest value of $0.65 \%$, namely the company Alam
Sutera Realty Tbk. in 2018. up to the highest value of $7.76 \%$, namely Bekasi Fajar Industrial Estate company in 2018. Variable Leverage has an average value of $1.63 \%$ with a standard deviation of $1.212 \%$, which means small data variations (less than $0.416 \%$ from mean). The Leverage variable ranges from the lowest value of $0.28 \%$, namely the Adhi Karya (Persero) Tbk company in 2014. to the highest value of $5.37 \%$, the Bekasi Fajar Industrial Estate company in 2014. The profitability variable measured by ROA has an average value of an average of $0.06 \%$ with a standard deviation of $0.038 \%$, which means that the variation of the data is small (less than $0.018 \%$ of the mean). The profitability variable measured by ROA ranges from the lowest 
value of $0.00 \%$, namely the Sentul City Tbk company in 2014 to the highest value of $0.22 \%$, the Bekasi Fajar Industrial Estate company in 2013.

\section{Test Prerequisite Analysis \\ Normality test}

Thus the overall results of the normality test calculation using the Lilliefors test can be seen in the summary in table 1.3 below:

Table-1.3: Summary of the Normality Test

\begin{tabular}{|c|c|c|c|c|c|c|}
\hline \multirow{2}{*}{ No } & \multirow{2}{*}{ Estimation } & \multirow{2}{*}{} & \multirow{2}{*}{$\mathbf{L}_{\text {count }}$} & \multicolumn{2}{|c|}{$\mathbf{L}_{\text {Tabel }}$} & \multirow{2}{*}{ Decision } \\
\cline { 5 - 6 } & & & & $\boldsymbol{\alpha}=\mathbf{0 . 0 5}$ & $\boldsymbol{\alpha}=\mathbf{0 . 0 1}$ & \\
\hline 1 & Y atas X1 & 78 & $-0,0247$ & 0,1003 & 0,1167 & Normal \\
\hline 2 & Y atas X2 & 78 & $-0,0294$ & 0,1003 & 0,1167 & Normal \\
\hline 3 & Y atas X3 & 78 & $-0,0748$ & 0,1003 & 0,1167 & Normal \\
\hline
\end{tabular}

\section{Multicollinearity Test}

The results of the tolerance calculation according to Table 1.4 show that there are no independent variables that have a tolerance value of less than $10 \%$; all tolerance values are more than 10\%; which means there is no correlation between variables. The results of the calculation of the value of the variance inflation factor (VIF) also show the same thing, there are no independent variables that have a VIF value of more than 10; the value of the variance inflation factor (VIF) is all less than 10. The conclusion is that there is no multicollinearity between the independent variables in the regression model based on the tolerance value test.
Tabel-1.4: Summary of Multicollinearity Test

\begin{tabular}{|c|c|c|c|}
\hline \multirow{2}{*}{ Model } & \multirow{2}{*}{ Variabel } & \multicolumn{2}{|c|}{ Collinearity Statistics } \\
\cline { 3 - 4 } & & Tolerance & VIF \\
\hline \multirow{3}{*}{1} & $\mathrm{X} 1$ & 0,998 & 1,002 \\
\cline { 2 - 4 } & $\mathrm{X} 2$ & 0,862 & 1,159 \\
\cline { 2 - 4 } & $\mathrm{X} 3$ & 0,861 & 1,161 \\
\hline
\end{tabular}

Source: Data processed (2019)

\section{Autocorrelation Test}

Autocorrelation test can be done by DurbinWatson (DW) testing. The results of the autocorrelation test can be seen in Table 1.5 below:

Tabel-1.5: Autocorrelation test results

\begin{tabular}{|c|c|c|c|c|c|c|c|}
\hline Model & $\mathbf{n}$ & $\mathbf{K}$ & $\mathbf{d l}$ & $\mathbf{d u}$ & $\begin{array}{c}\text { Durbin } \\
\text { Watson }\end{array}$ & $\mathbf{4 - d \boldsymbol { u }}$ & $\mathbf{4 - \boldsymbol { l } \boldsymbol { l }}$ \\
\hline 1 & 78 & 3 & 1,554 & 1,713 & 1,891 & 2,287 & 2,447 \\
\hline
\end{tabular}

Source: Data processed (2019)

Referring to Ghozali [11], the regression model in this study is free from the autocorrelation problem because the Durbin Watson values are between du and $4 \mathrm{du}$.

\section{Heteroscedasticity Test}

The test results using the Spearman rank test can be seen in the following table 1.6:

Tabel-1.6: Heteroscedasticity Test Results

\begin{tabular}{|l|c|l|c|c|c|}
\hline \multicolumn{2}{|c|}{ Abres } & Correlation Coefficient & $\mathbf{X 1}$ & $\mathbf{X 2}$ & $\mathbf{X 3}$ \\
\cline { 2 - 6 } Spearman's rho & \multirow{3}{*}{ Sig. (2-tailed) } & 0,403 & $0,356^{* *}$ & $-0,356^{* *}$ \\
\cline { 3 - 6 } & & $\mathrm{N}$ & 78 & 78 & 0,071 \\
\hline & & & 78 \\
\hline
\end{tabular}

Source: Data processed (2019)

Spearman rank test results in the table above show the significance value of each variable of 0.403 , 0.071 , and 0.071. Because the significance value of each variable is greater than 0.05 , it can be concluded that the data are free from heterocedasticity.

\section{Hypothesis test \\ Multiple regression analysis}

Multiple regression analysis is used to get the regression coefficient which will determine whether the hypothesis made will be accepted or rejected. By using the multiple linear regression method the following results are obtained:

Tabel-1.7: Results of Regression Analysis

\begin{tabular}{|c|c|c|c|c|c|c|c|c|}
\hline & Model & B & $\mathbf{T}$ & Sig & $\mathbf{T}$ & $\operatorname{adi} \mathbf{R}^{2}$ & $F$ & Sig \\
\hline \multirow{4}{*}{1} & (Constant) & 0,080 & count & & \multirow{4}{*}{1,665} & \multirow{4}{*}{0,121} & \multirow{4}{*}{4,542} & \multirow{4}{*}{0,006} \\
\hline & $\mathrm{X} 1$ & 0,064 & 0,144 & 1,348 & & & & \\
\hline & $\mathrm{X} 2$ & $-0,003$ & $-0,112$ & $-0,971$ & & & & \\
\hline & X3 & $-0,013$ & $-0,399$ & $-3,469$ & & & & \\
\hline
\end{tabular}

Source: Data processed (2019) 
Based on the results of the regression tests above, an equation can be formed as follows: $\mathrm{Y}=0,080$ $+0,064 X_{1}-0,003 X_{2}-0,013 X_{3}+\varepsilon_{1}$

\section{Determination Coefficient Test $\left(\mathbf{R}^{2}\right)$}

From table 1.7 it is known that the adjusted $\mathrm{R}$ square value is 0.121 . This means that $12.1 \%$ of the profitability variable measured by ROA can be explained by the variation of the independent variables namely Working Capital Turnover, Liquidity and Leverage, the remaining $76.1 \%(100 \%-23.9 \%)$ is explained by other causes outside the model.

\section{Simultaneous Significance Test (Statistical Test F)}

From the Anova test or the F test in table 1.7 above, the calculated $F$ value is 4.542 with a significance probability that indicates 0.006 . Test probability values are much smaller than $\alpha=0.05$. This shows that together (simultaneously) Profitability variables measured by ROA can be explained by variations in independent variables namely Working Capital Turnover, Liquidity and Leverage.

\section{Significance Test of Individual Parameters (t Test)}

$\mathrm{T}$ test is performed to determine whether the independent variables in the regression model have an individual effect on the dependent variable. To determine whether a hypothesis is accepted or rejected is to compare $t$ arithmetic with ttable and the significance value in this study using a significance level of 0.05 . In this case, the table value is 1.665 .

Partial test results ( $\mathrm{t}$ test) in table 1.7 above indicate that the variable working capital turnover does not affect profitability, which can be seen from the comparison between $t_{\text {table }}$ and $t_{\text {count }}$, namely $t_{\text {table }}>t_{\text {count }}$, with a value of ttable 1.665 and $t_{\text {count }} 1.348$ and $a$ significance level that is located above 0.05 . Thus $\mathrm{Ha}_{1}$ was rejected.

Liquidity variable does not affect profitability, which can be seen from the comparison between $t_{\text {table }}$ and $t_{\text {count }}$, namely $t_{\text {table }}>t_{\text {hitung }}$, with a value of $t_{\text {table }} 1.665$ and $t_{\text {count }}-0.971$ and a significance level above 0.05 . Thus $\mathrm{Ha}_{2}$ rejected.

The leverage variable has a negative effect on profitability, which can be seen from the comparison between $t_{\text {table }}$ and $t_{\text {count }}$, namely $t_{\text {table }}<$ tcount, with a $t_{\text {table }}$ value of 1.665 and $t_{\text {count }}-3.469$ and a significance level below 0.05 . Thus $\mathrm{Ha}_{3}$ received.

\section{DISCUSSION}

\section{Working capital turnover affects profitability}

Based on partial research results, it can be seen that working capital turnover has no effect on profitability. These results indicate that any increase in variable working capital turnover cannot increase profitability. The results of this study are in line with research conducted by Wijaya and Isnani [16] which states that working capital turnover has no effect on profitability. But contrary to research conducted by Yulianita and Isynuwardhana [17] which states that working capital turnover affects profitability.

Based on the data obtained shows that during 2013-2018 the level of working capital turnover in the sample companies experienced an unstable increase and decrease. This is due to the increase and decrease in profitability not only reflected in working capital turnover, but there are other factors that affect profitability. This can be seen from the data that has been processed which shows that information about the increase or decrease in working capital turnover is not always followed by an increase and decrease in profitability in the sample companies.

\section{Liquidity affects profitability}

Based on partial research results, it can be seen that liquidity has no effect on profitability. These results indicate that any increase in variable liquidity cannot increase profitability. This means that the high or low ability of companies to pay short-term obligations does not affect the size of the profits received by the company. Cash and inventory turnover owned by the company from its working capital is used to pay shortterm obligations with no effect on corporate profits.

The results of this study are in line with research conducted by Yulianita and Isynuwardhana [17] which states that liquidity has no effect on profitability. But contrary to research conducted by Wijaya and Isnani [16] which states that liquidity affects profitability.

\section{Leverage affects profitability}

Based on partial research results, it can be seen that leverage has a negative effect on profitability. These results indicate that any increase in leverage can reduce profitability. Companies that have high DER tend to have low ROA. Conversely companies that have a low DER tend to have high ROA. DER illustrates the extent to which owner's capital can cover debts to outside parties [19]. The smaller the DER, the better. For the security of outsiders the best ratio if capital is greater than the amount of debt or at least the same. A high DER value influences ROA acquisition, which causes the acquisition of a company's ROA value to be low. This is due to the payment of fees incurred by a higher debt or loan. Declining corporate profits cause the value of ROA to be low.

The results of this study are in line with research conducted by Yulita, et al. [17] and Yulianita \& Isynuwardhana $[17,20]$ that leverage affects profitability.

\section{CONCLUSIONS}

Based on the results of the analysis and discussion that has been carried out, the following 
conclusions can be drawn: 1) Working capital turnover has no effect on profitability; 2) Liquidity has no effect on profitability; and 3) Leverage has a negative effect on profitability.

\section{SUGGESTIONS}

By considering the existing limitations, it is expected that future research will improve the following factors: 1) For companies, corporate financial managers must consider and consider the effect of liquidity on profitability in companies where the low cash owned by the company must be used sufficiently for the purposes and company investment, so that the profits obtained by the company increase .. 2) For investors, in determining the financial strategy can consider the funding decision factors relating to the portion of debt. Investors should be careful about investing in companies with high debt structures because they have a high risk of bankruptcy. Investors are advised to choose to invest in large companies that are more established in terms of total assets and companies that have a good level of profitability. 3) For further researchers, it is expected to conduct further research using different company financial ratios, which have not been included in the model this research or by adding other independent variables that are thought to influence profitability.

\section{REFERENCES}

1. Kasmir. (2013). Analisis Laporan Keuangan. Jakarta: Rajawali Pers.

2. Agus Riyanto. (2013). Kapita Selekta Kuesioner Pengetahuan dan Sikap Dalam. Penelitian Kesehatan. Jakarta: Salemba Medika

3. Nugroho, A., Visser, J., \& Kuipers, T. (2011, May). An empirical model of technical debt and interest. In Proceedings of the 2nd Workshop on Managing Technical Debt (pp. 1-8). ACM.

4. Bambang R. (2012). Dasar-Dasar Perbelanjaan Perusahaan. Edisi Keempat. Yogyakarta: BPFE

5. Satriya, I. M. D., \& Lestari, P. V. (2014). Pengaruh Perputaran Modal Kerja Terhadap Profitabilitas Perusahaan. E-Jurnal Manajemen, 3(7).

6. Riana, D., \& Diyani, L. A. (2016). Pengaruh Rasio Keuangan dalam Memprediksi Perubahan Laba pada Industri Farmasi (Studi Kasus pada BEI Tahun 2011-2014). Jurnal Online Insan Akuntan, 1(1), 16-42.

7. Dobrow Riza, S., Ganzach, Y., \& Liu, Y. (2018). Time and job satisfaction: A longitudinal study of the differential roles of age and tenure. Journal of Management, 44(7), 2558-2579.

8. Jensen, M. C., \& Meckling, W. H. (1976). Theory of the firm: Managerial behavior, agency costs and ownership structure. Journal of financial economics, 3(4), 305-360.

9. Lukman, F. (2015). Epistemologi Intuitif dalam
Resepsi Estetis HB Jassin terhadap AlQur'an. Journal of Qur'an and Hadith Studies, 4(1), 37-55.

10. Irham Fahmi. (2014). Dalam Pengantar Manajemen Keuangan. Bandung: Alfabeta

11. Munawir, S. (2010). Analisa Laporan Keuangan (edisi keempat). Yogyakarta: Liberty

12. Rista Bintara dan Putri Renalita Sutra Tanjung. (2019). Analysis of Fundamental Factors on Stock Return. International Journal of Academic Research in Accounting, Finance and Management Sciences, 9(2).

13. Dari, W., Harnovinsah. (2017). Pengaruh Resiko Kredit (Non Performing Loan),Tingkat Kecukupan Modal (Capital Adequacy Ratio), dan Loan to Deposit Ratio terhadap Tingkat Profitabilitas pada Perusahaan Perbankan yang terdaftar di BEI Periode 2012-2015. Profita, 10(3).

14. Indracahya, E., \& Faisol, D.A. (2017). The Effect of Good Corporate Governance Elements, Leverage, Firm Age, Company Size and Profitability on Earning Management (Empirical Study of Manufacturing Companies in Bei 20142016). Profita. 10(2).

15. Panji Putranto. (2019). Pengaruh Strategi Diversifikasi, Leverage, dan Inflasi Terhadap Profitabilitas Perusahaan Food \& Beverage. Jurnal online insan akuntan. 4(2) Desember

16. Indra Wijaya dan Nurlaila Isnani. (2019). Pengaruh Efisiensi Modal Kerja, Likuditas, dan Solvabilitas terhadap Profitabilitas Perusahaan Farmasi. Jurnal online insan akuntan 4(2) Desember

17. Fitri Ayu Yulianita dan Deannes Isynuwardhana. (2019). Pengaruh Perputaran Modal Kerja, Likuiditas, dan Leverage Terhadap Profitabilitas (Studi Empiris pada Perusahaan Barang Konsumsi yang Terdaftar di Bursa Efek Indonesia Periode 2015-2017). E-Proceeding of Management, 6(2). Agustus

18. Aditya Mahendra Putra, Irene Rini Demi Pangestuti. (2019). Pengaruh Struktur Pasar, Kompetisi, Diversifikasi, dan Risiko Kredit Terhadap Profitabilitas Bank Dengan Bank Size Sebagai Variabel Kontrol (Studi Pada Bank Yang Terdaftar di Bursa Efek Indonesia). Diponegoro journal of management, $8(1)$.

19. Harahap, E., Sakamoto, W., Nishi, H.(2010). Failure prediction method for network management system by using Bayesian network and shared database. In8th Asia-Pacific Symposium on Information and Telecommunication Technologies, 1-6

20. Ikatan Akuntan Indonesia. (2007). Standar Akuntansi Keuangan. Jakarta: Salemba Empat www.idx.co.id 